\section{Human Conception in Vitro: Proceedings of the First Bourn Hall Meeting}

Eds R G Edwards and Jean $M$ Purdy. London, Academic Press, 1982. £20.

\section{Test Tube Babies. A Guide to Moral Questions, Present Techniques and Future Possibilities}

Eds W A W Walters and P Singer. Melbourne, Oxford University Press, 1982. Paperback £5.95.

The difference between these two books is indicated by their titles. The first is a work of medical science; the second a journalistic commentary.

Edwards and Purdy have organised their papers in four sections in logical sequence, concerning the natural and stimulated cycle, the follicle, fertilisation and early growth in vitro, and the phasing of the replacement of embryos. Each is followed by verbatim discussion. A fifth groups 'essential topics' - from idiopathic infertility to amniocentesis and fetal growth. As is proper, ethical questions are raised in connection with the processes described. There is also one paper specific to the ethics of in vitro fertilisation (IVF) - a defensive paper, understandably, ending with a banal reflection on the USA's obsession with the separation of civil from religious authority, which adds little to the ethics under discussion. And Edwards, in a final paper, invites ethical discussion of foreseeable developments in investigation and clinical application.

Among the practice-related ethical questions are these. There are instances when observation, for example by laparoscopy, sonography or photography may affect the process studied. There are figures comparing the number of healthy fetuses damaged or lost by amniocentesis with the number of severely malformed fetuses having low life-expectancy actually diagnosed - leading to a general inclination against amniocentesis for IVF pregnancies. The ethics of care determine exacting standards in the collecting and culture of spermatozoa and oocytes, even in the design of buildings and equipment. The poorer fertilisation rate of semen containing bacterial or viral infections dictates selective and remedial procedures.
The destiny of spare embryos - the third or fourth after one or two have been implanted - is discussed: may they be used for observation or experiment (with a view to improving clinical practice or to the elimination in vitro of deleterious genes or chromosomal disorders) or must they be implanted somewhere, to take their chance, as an unwanted triplet or quadruplet, or simply to let 'nature' reject what man cannot bring himself to discard?

Edwards's final chapter must be studied in its entirety. He outlines studies which could purposefully be made of human embryos at stated stages of growth, and of their constituent tissues, all in vitro, and asks why he may not, if he may not, make them. Can he validate his future programme of work as he has validated every step in the past? Or is society to attribute to preimplantation embryos such inviolable status as to prohibit all investigative and experimental use of them? The book as a whole is essential reading for moralists who intend to engage in serious discussion of the issues.

Test Tube Babies is a collection of pieces put together in Melbourne from sources so disparate as the Department of Obstetrics and Gynaecology at Monash University, a Jesuit theological college and other schools of divinity, and miracle stories and heartfelt correspondence in The Age newspaper.

The simple description of IVF processes in the first chapter is adequate: it would serve readers who could never master Edwards and Purdy. After that the pendulum swings. Helga Kuhse's chapter on 'what ethics is all about' is remarkable only for the statement that John Donne wrote 'in the wake of Charles I's violent death'. Charles I was executed in 1649; Donne died in 1631. Serious reflection begins with B Johnstone, who acknowledges (but does not embrace) the existence of a long, tolerant tradition based on the philosophical speculation of an 'animation' delayed until the body is formed enough to receive the soul; but he bases his own case that the early human embryo is a person deserving of respect on probability, on there being a four out of five chance of its becoming one. Kuhse and Singer together cannot accord to it a moral status different from that of sperm and ovum separately, despite the advance in potential arising from their fusion. (The trouble with Singer, incidentally, is that he makes those who might rationally be disposed to accept his conclusions squirm at his method of reaching them.)

The chapter on consent is unneces- sarily polarised between the diametrical $T$ extremes of Paul Ramsey and Joseph $\overrightarrow{\overline{\bar{V}}}$.

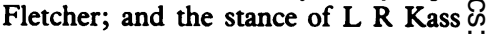
and the Protestant Ramsey, hostile to IVF, is joined to that of Pius XII in $\stackrel{5}{+}$ W J Daniel's relating of IVF to the ethics of sex and begetting. No one $\frac{\bar{\sigma}}{\sigma}$ would deny that these opponents are defending a human good in the integrat- $\stackrel{\overparen{D}}{\varnothing}$ ing of procreation with sexual love and family life; the only question is, why do $\omega$ they believe that good to be so $\vec{\circ}$ threatened by IVF? Are they lacking in a sense of proportion?

J A Henley and J L Morgan attempt medial positions, a trial period for IVF $\overline{\overline{3}}$ and embryo replacement (ER) within $\Phi$ marriage, for instance, but not outside $\vec{\circ}$ it. A A Rassaby's attempt to sketch iv legislation complicated enough to cover $\bullet$ all the openings for abuse in surrogate 0 motherhood invites the conclusion that the attempt were better not made. $\vec{c}$ Walters speculates on cloning, ectogenesis and hybrids as possible $\overparen{(D}$ things to come, but without the discip- $\overrightarrow{0}$ lined control which makes Edwards's questions the more worth attending to. An appendix gives the ethical guidelines for clinicians and scientists working in these fields in the Queen Victoria Medical Centre, Melbourne.

GR DUNSTAN $\stackrel{\varrho}{\Phi}$
Department of Theology, University of
Exeter $\frac{\overline{0}}{3}$

\section{Biomedical Ethics Reviews 1983}

Eds James $M$ Humber and Robert $F_{\sigma}^{\frac{\Phi}{\sigma}}$ Almeder. Clifton, New Jersey, Humana Press, 1983. In the USA $\$ 24.50$, elsewhere $\$ 34.50$.

Literature in contemporary bioethics is을 being published at a staggering rate. $D$ Even within the last decade forms of technology which only recently were categorised as science-fiction are now. developed as workable options. The N need to keep informed is keenly felt byN్W many but the question of where to begin $\sigma$ in the literature can prove a stumbling block to keeping pace. This volume, the first in a planned series, is an attempt to answer this need. Two questions are the ${ }^{-+}$ focus of the volume: what is being? offered through bio-chemical research and medical technology, and what are the implications (social, ethical, politi- $\overrightarrow{\mathbb{Q}}$ cal, economic) of the rapidly expanding $\frac{}{\sigma}$ technology? The objective of the pub-< lisher is to provide a biennial review of developments in biomedical ethics, continuing to pose the two questions cited above, and to solicit previously 